\title{
Zechi-Ceide syndrome
}

INSERM

\section{Source}

INSERM. (1999). Orphanet: an online rare disease and orphan drug data base. ZechiCeide syndrome. ORPHA:217017

Zechi-Ceide syndrome is a rare, genetic, multiple cong enital anomalies/dysmorphic syndrome characterized by occipital atretic cephalocele associated with a specific facial dysmorphism (consisting of prominent forehead, narrow palpebral fissures, midface deficiency, narrow, malformed ears, broad nose and nasal root, grooved nasal tip and columella, laterally angulated, hypoplastic nares, short philtrum, thin upper lip, clift lip/palate, severe oligodontia, prominent chin) and large feet with sandal gap. Intellectual disability, developmental delay and hypoplastic finger and toenails have also been reported. 